\title{
(2) OPEN ACCESS \\ Cancer within the family tree: risks, diagnosis and treatment of juvenile polyposis syndrome
}

\author{
Kyler Kozacek, ${ }^{1}$ Ryan Luzano Santos (0 ,' Michael Abdo, ${ }^{1}$ Pedro A Manibusan²
}

${ }^{1}$ Medicine, Tripler Army Medical Center, Honolulu, Hawaii, USA ${ }^{2}$ Gastroenterology, Tripler Army Medical Center, Honolulu, Hawaii, USA

\section{Correspondence to} Dr Ryan Luzano Santos; rysantos671@gmail.com

Accepted 9 July 2020

\section{DESCRIPTION}

A 41-year-old woman with irritable bowel syndrome symptoms presented for colonoscopy after her mother was diagnosed with multiple juvenile colon polyps positive for Bone morphogenic protein receptor type-1A (BMPR1A) mutation and subsequently colon cancer at age 64 . Colonoscopy revealed multiple irregular pedunculated polyps $(1-4 \mathrm{~cm})$, including the tubular adenoma in figure 1 , and a circumferential, broad-based $4-5 \mathrm{~cm}$ tubulovillous adenoma seen in figure 2 that nearly completely obstructed the mid-ascending colon. Biopsies revealed tubular adenomas and tubular villous adenomas with positive BMPR1A mutation suggesting juvenile polyposis syndrome (JPS).

JPS is clinically diagnosed in the absence of other hamartomatous polyposis syndromes, including Peutz-Jeghers and Cowden with the presence of either greater than five juvenile polyps in the colorectum, multiple juvenile polyps elsewhere in GI tract or any polyps with family history of juvenile polyps. ${ }^{12}$ Presence of JPS confers a cumulative colorectal cancer risk of $68 \%$ by age 60 years. ${ }^{2}$

BMPR1A is an autosomal dominant gene mutation that affects the transforming growth factorbeta pathway leading to hundreds of polyps often within the first decade of life. Mutations are found in nearly $60 \%$ of JPS cases. ${ }^{2}$

At-risk JPS patients imperatively need genetic testing for both SMAD4 and BMPR1A gene mutations to determine appropriate cancer screening. Current European Society of Gastrointestinal Endoscopy guidelines suggest early screening of the stomach at age 18 years and colon as early as age 12 years, as the single most impacting factor in outcomes of patients and their families. ${ }^{3}$ Our patient was referred to general surgery for resection of mass.

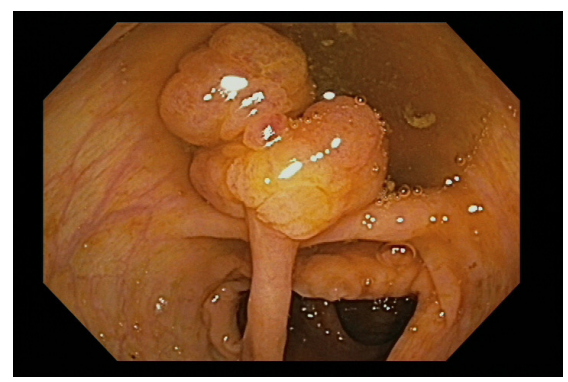

Figure 1 Tubular adenoma found in the mid ascending colon.

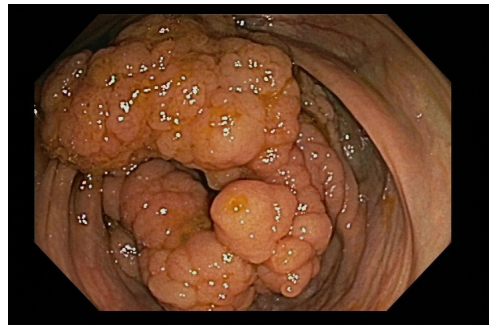

Figure 2 Nearly obstructing $4-5 \mathrm{~cm}$ tubulovillous adenoma in mid-ascending colon.

Contributors All persons who meet authorship criteria are listed as authors, and all authors certify that they have participated sufficiently in the work to take public responsibility for the content, including participation in patient care, analysis, writing, and revision of the manuscript. PM was main physician responsible for direct patient care while KK and RLS were main writers of the manuscript. MA was involved with significant research and editorial assistance. Furthermore, each author certifies that this material or similar material has not been and will not be submitted to or published in any other publication before its appearance in the Postgraduate Medical Journal BMJ.

Funding The authors have not declared a specific grant for this research from any funding agency in the public, commercial or not-for-profit sectors.

Competing interests None declared.

Patient consent for publication Obtained.

Provenance and peer review Not commissioned; externally peer reviewed.

Open access This is an open access article distributed in accordance with the Creative Commons Attribution Non Commercial (CC BY-NC 4.0) license, which permits others to distribute, remix, adapt, build upon this work non-commercially, and license their derivative works on different terms, provided the original work is properly cited and the use is non-commercial. See: http://creativecommons.org/licenses/by-nc/4.0/.

\section{Learning points}

Juvenile polyposis syndrome (JPS) is clinically diagnosed in the absence of other hamartomatous polyposis syndromes with the presence of either greater than five juvenile polyps in the colorectum, multiple juvenile polyps elsewhere in the gastrointestinal tract or any polyps with family history of juvenile polyps.

- JPS confers a cumulative colorectal cancer risk of $68 \%$ by age 60 years.

- European Society of Gastrointestinal Endoscopy guidelines recommend patients with JPS to undergo early screening of colon as early as age 12 years and stomach at age 18 years via Esophagogastroduodenoscopy. 
Images in...

ORCID iD

Ryan Luzano Santos http://orcid.org/0000-0002-0403-3809

\section{REFERENCES}

1 Patel R, Hyer W. Practical management of polyposis syndromes. Frontline Gastroenterol 2019:10:379-87.
2 Katabathina VS, Menias CO, Khanna L, et al. Hereditary gastrointestinal cancer syndromes: role of imaging in screening, diagnosis, and management. Radiographics 2019;39:1280-301

3 van Leerdam ME, Roos VH, van Hooft JE, et al. Endoscopic management of polyposis syndromes: European Society of gastrointestinal endoscopy (ESGE) guideline. Endoscopy 2019;51:877-95.

Copyright 2020 BMJ Publishing Group. All rights reserved. For permission to reuse any of this content visit

https://www.bmj.com/company/products-services/rights-and-licensing/permissions/

BMJ Case Report Fellows may re-use this article for personal use and teaching without any further permission.

Become a Fellow of BMJ Case Reports today and you can:

Submit as many cases as you like

- Enjoy fast sympathetic peer review and rapid publication of accepted articles

Access all the published articles

Re-use any of the published material for personal use and teaching without further permission

Customer Service

If you have any further queries about your subscription, please contact our customer services team on +44 (0) 2071111105 or via email at support@bmj.com.

Visit casereports.bmj.com for more articles like this and to become a Fellow 